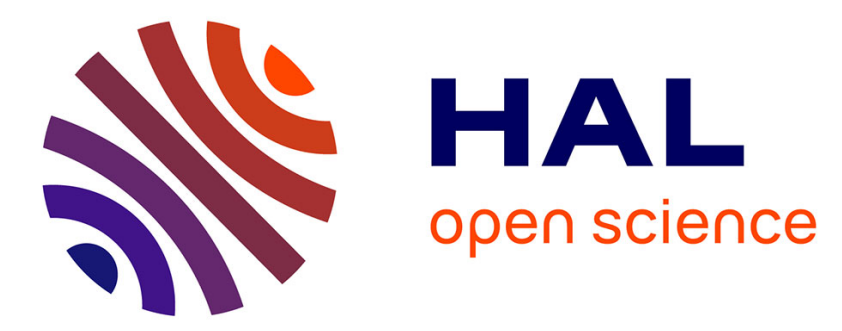

\title{
Microstructure and Mechanical Behaviour of NbTiAl based alloys doped with low additions of silicon.
}

\author{
Z. Zhao, A. Denquin, S. Drawin, J. Barreau
}

\section{To cite this version:}

Z. Zhao, A. Denquin, S. Drawin, J. Barreau. Microstructure and Mechanical Behaviour of NbTiAl based alloys doped with low additions of silicon.. THERMEC 2013, Dec 2013, LAS VEGAS, United States. hal-01057810

\section{HAL Id: hal-01057810 \\ https://hal-onera.archives-ouvertes.fr/hal-01057810}

Submitted on 25 Aug 2014

HAL is a multi-disciplinary open access archive for the deposit and dissemination of scientific research documents, whether they are published or not. The documents may come from teaching and research institutions in France or abroad, or from public or private research centers.
L'archive ouverte pluridisciplinaire HAL, est destinée au dépôt et à la diffusion de documents scientifiques de niveau recherche, publiés ou non, émanant des établissements d'enseignement et de recherche français ou étrangers, des laboratoires publics ou privés. 


\title{
Microstructure and Mechanical Behaviour of NbTiAl based alloys doped with low additions of silicon
}

\author{
Zhao ZHAO ${ }^{1, \text { a }}$, Anne DENQUIN ${ }^{1, b}$, Stefan DRAWIN ${ }^{1, c}$ \\ Jonathan BARREAU ${ }^{1, d}$ \\ ${ }^{1}$ ONERA- The French Aerospace Lab, F-91761 Palaiseau, France
}

zhao.zhao@onera.fr,$\frac{\text { anne.denquin@onera.fr }}{\text { jonathan.barreau@onera.fr }}$ stefan.drawin@onera.fr,

Keywords: Nb-base alloy; Silicides; Niobium aluminides; Phase transformation; Mechanical properties

\begin{abstract}
Nb-base refractory intermetallic materials have potential interest for high temperature applications thanks to their low density and high temperature strength. While advanced intermetallics in monolithic form have limited prospects for providing the required balance of properties for use at high temperatures, two-phase or multicomponent intermetallic systems composed of a ductile, Nb-base refractory phase in equilibrium with one or more silicide intermetallics show promise for further development as structural materials. In the present paper, $\mathrm{Nb}$-base refractory alloys based on $\mathrm{Nb}-35 \mathrm{Ti}-15 \mathrm{Al}$ (at.\%) were doped with small amount of Si (1 and 2 at\% of silicon) addition to improve its high temperature strength by keeping an acceptable ductility at room temperature. The samples were prepared by arc-melting starting from pure elements (99.99\%). The silicon addition effects on the microstructural features were investigated by using X Ray Diffraction (XRD), Scanning Electron Microscopy (SEM) techniques. Its effects on the mechanical properties were assessed by compression tests at ambient and high temperatures. Compression tests show the beneficial effect of the Si addition on strength.
\end{abstract}

\section{Introduction}

Since 1980's, there has been significant research into the exploration of intermetallic alloy systems capable of operation at high temperatures. While the intermetallic systems are known for their exceptional strength and creep resistance at elevated temperatures, they are also known for their brittleness at low temperatures. Numerous investigations have been conducted on $\mathrm{Nb}$-rich alloys related to the phase equilibria between the $\beta_{0}(\mathrm{~B} 2)$ and $\mathrm{Nb}_{3} \mathrm{Al}(\delta, \mathrm{A} 15)$ phases [1-6], as well as the mechanical properties of these alloys [7-14]. One of the alloy development strategy was to associate $\mathrm{Nb}_{3} \mathrm{Al}$ phase in a $\mathrm{Nb}_{\mathrm{ss}}$ (B2 structure type) ductile matrix in order to improve the fracture toughness of the $\mathrm{Nb}_{3} \mathrm{Al}$ phase at low temperature. However, this alloy system leads to an appreciable decrease in strength at high temperature [15]. Therefore, further studies are needed to increase the high temperature strength in $\mathrm{Nb}_{\mathrm{ss}}$ as well as $\mathrm{Nb}_{3} \mathrm{Al}$ by means of alloying it with element such as $\mathrm{Si}$, Hf or $\mathrm{Zr}$.

In the present study, the effects of alloying $\mathrm{Nb}_{\mathrm{ss}} / \mathrm{Nb}_{3} \mathrm{Al}$ with a low amount of silicon were examined in three different cast alloys (0at.\%Si, 1at.\%Si and 2at.\%Si). The silicon addition effects on the microstructural features were investigated by using X-Ray Diffraction (XRD) and Scanning Electron Microscopy (SEM) techniques. Its effects on the mechanical properties were assessed by compression tests at ambient and high temperatures.

\section{Experiment}

$60 \mathrm{~cm}^{3}$ ingots of alloys used in the study were made from high purity $\mathrm{Nb}(99.99 \%), \mathrm{Al}(99.99 \%)$, $\mathrm{Ti}(99.99 \%)$ and $\mathrm{Si}(99.99 \%)$ by vacuum arc-melting in a water-cooled copper hearth and using a 
non-consumable tungsten electrode. Each ingot was remelted 4-6 times to ensure complete mixing of the constituents. The chemical compositions of the three alloys are shown in Table 1.

\begin{tabular}{|c|c|c|c|c|c|}
\hline Alloy reference & Ch. Composition & Nb [at.\%] & Ti [at.\%] & Al [at.\%] & Si [at.\%] \\
\hline M1 & Nb-34Ti-15Al & 51.5 & 34.7 & 13.8 & - \\
M2 & Nb-33.6Ti-15Al-1Si & 50.7 & 33.8 & 14.3 & 1.2 \\
M3 & Nb-33.2Ti-15Al-2Si & 49.9 & 33.9 & 14.1 & 2.1 \\
\hline
\end{tabular}

Table1- Nominal and actual chemical compositions in at.\% of alloys investigated.

Two homogenization treatments were tested on the as-cast ingots: $1400^{\circ} \mathrm{C}$ for $24 \mathrm{~h}$ and $1200^{\circ} \mathrm{C}$ for $50 \mathrm{~h}$ in an inert atmosphere. Samples were wrapped in $\mathrm{Nb}$ foil prior to treatment. Metallographic samples of the cast and heat treated alloys were examined through back-scatter electron imaging (BSE). Energy dispersive spectrometry (EDS) analyses were used to obtain estimation of the chemical composition of areas in the microstructures. Phase identification was performed by X-ray diffraction (XRD). Foils for transmission electron microscopy (TEM) were prepared by using a variable angle Precision Ion Polishing System (PIPS).

Compression tests were conducted at room temperature and under vacuum at $800^{\circ} \mathrm{C}$ at a strain rate of $10^{-4} \mathrm{~s}^{-1}$.

\section{Results \& Discussion}

\subsection{Microstructure and phase analysis}

\section{As-cast}

The as-cast materials of the three $\mathrm{Nb}$-rich alloys were examined through various techniques to identify the primary solidification regions. All of the three alloys display a dendritic solidification microstructure (Fig. 1a-c). In M2 alloy containing 1at.\% of Si, the as-cast microstructure is very similar to M1 alloy (Fig. 1a) and none of silicide was observed (Fig. 1b). Whereas M3 alloy, with 2 at.\% of Si, exhibit primary silicide precipitates (black precipitates) (Fig. 1c) mainly located in the interdentritic (Fig. 1d). In each case, the $\mathrm{Nb}$ matrix was identified to be the disordered $\beta$ (bcc) phase through XRD phase identification technique (Fig. 2).
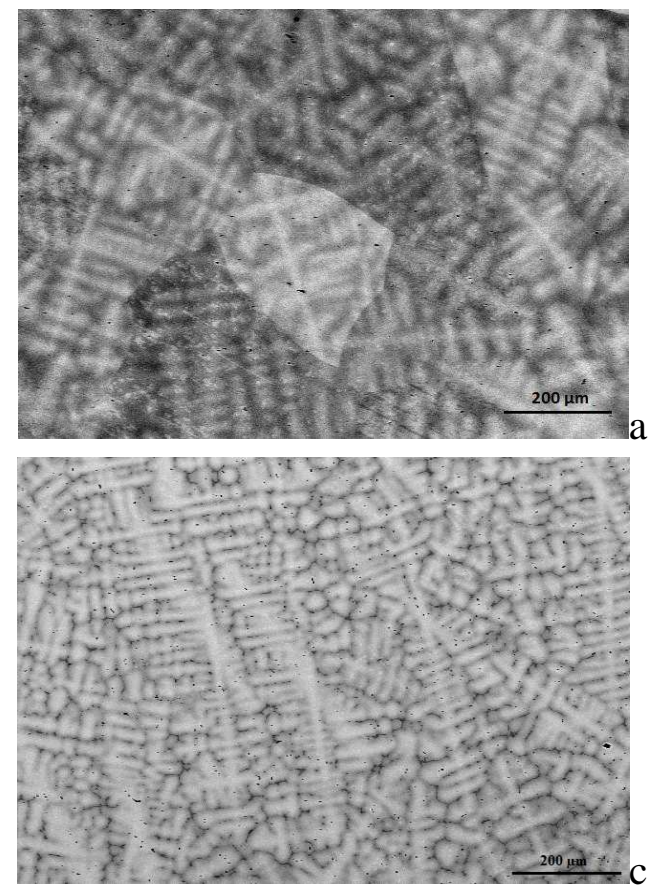
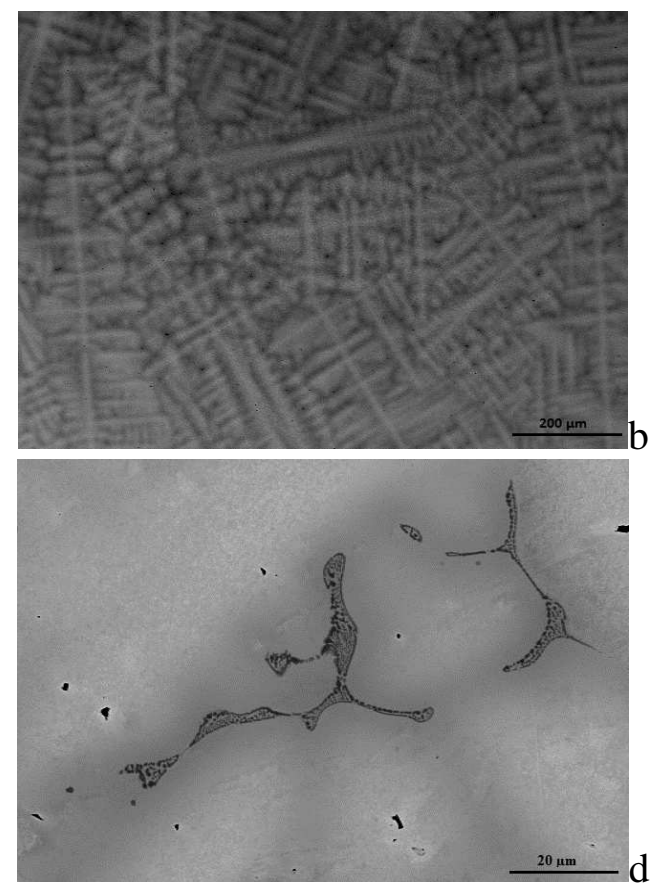

Fig. 1. Representative microstructures with BSE imaging of as-cast conditions, (a) of the M1 alloy, (b) of the M2 alloy with 1 at.\% of Si, showing none presence of silicide, (c) and (d) of the M3 alloy showing a precipitation of silicide mainly located at interdendritic spaces. 


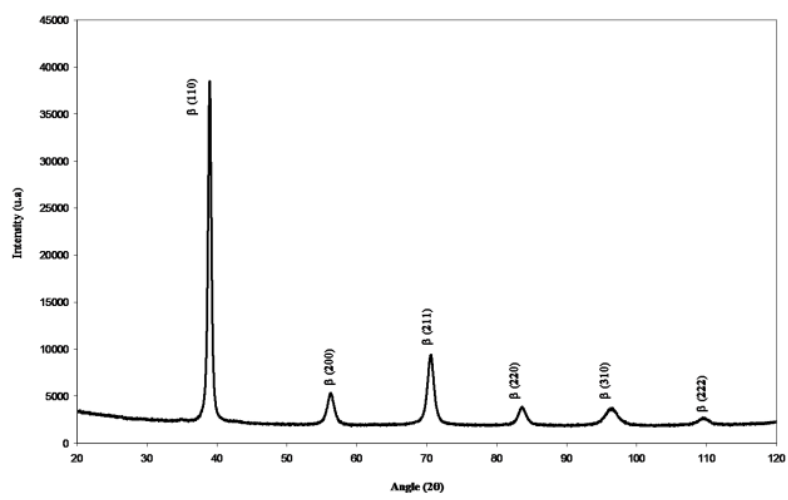

(a)

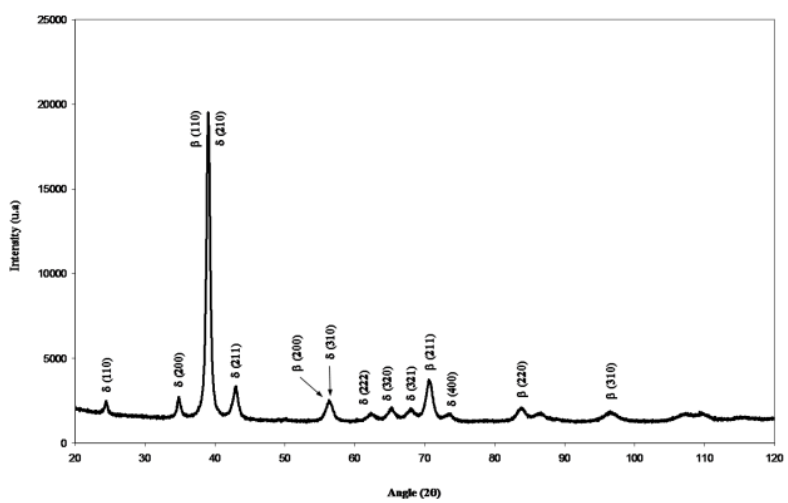

(b)

Fig. 2. (a) XRD pattern of the solid solution phase of the M1 alloy in as-cast condition (b) XRD pattern of M3 alloy treated at $1200^{\circ} \mathrm{C} / 50 \mathrm{~h}$.

\section{$1200^{\circ} \mathrm{C} / 50 \mathrm{~h} /$ furnace cooling}

Following the heat treatment at $1200^{\circ} \mathrm{C} / 50 \mathrm{~h}$, the $\mathrm{M} 3$ alloy displays an extensive precipitation of a second phase (Fig. 3c) was identified through XRD to be the $\delta$-phase $\left(\mathrm{Nb}_{3} \mathrm{Al}\right.$ ) (Fig.2b). These observations were confirmed by EDS analysis showing a chemical composition type ( $\mathrm{Nb}, \mathrm{Ti})_{3}(\mathrm{Al}$, Si) (Table 2). Furthermore, the presence of black precipitates located at grain boundary was revealed by BSE image (Fig. 3d) and identified to be the $(\mathrm{Ti}, \mathrm{Nb})_{5}(\mathrm{Si}, \mathrm{Al})_{3}$ type silicide. The $\delta$-phase has been also detected in alloy M2 (Fig. 3b) but to a lesser extent than in alloy M3 and none silicide was observed. The M1 alloy ( 0 at.\% Si), exhibits an equiaxed grains microstructure, the dendritic solidification microstructure has been erased after the treatment of $1200^{\circ} \mathrm{C} / 50 \mathrm{~h}$ (Fig. 3a).
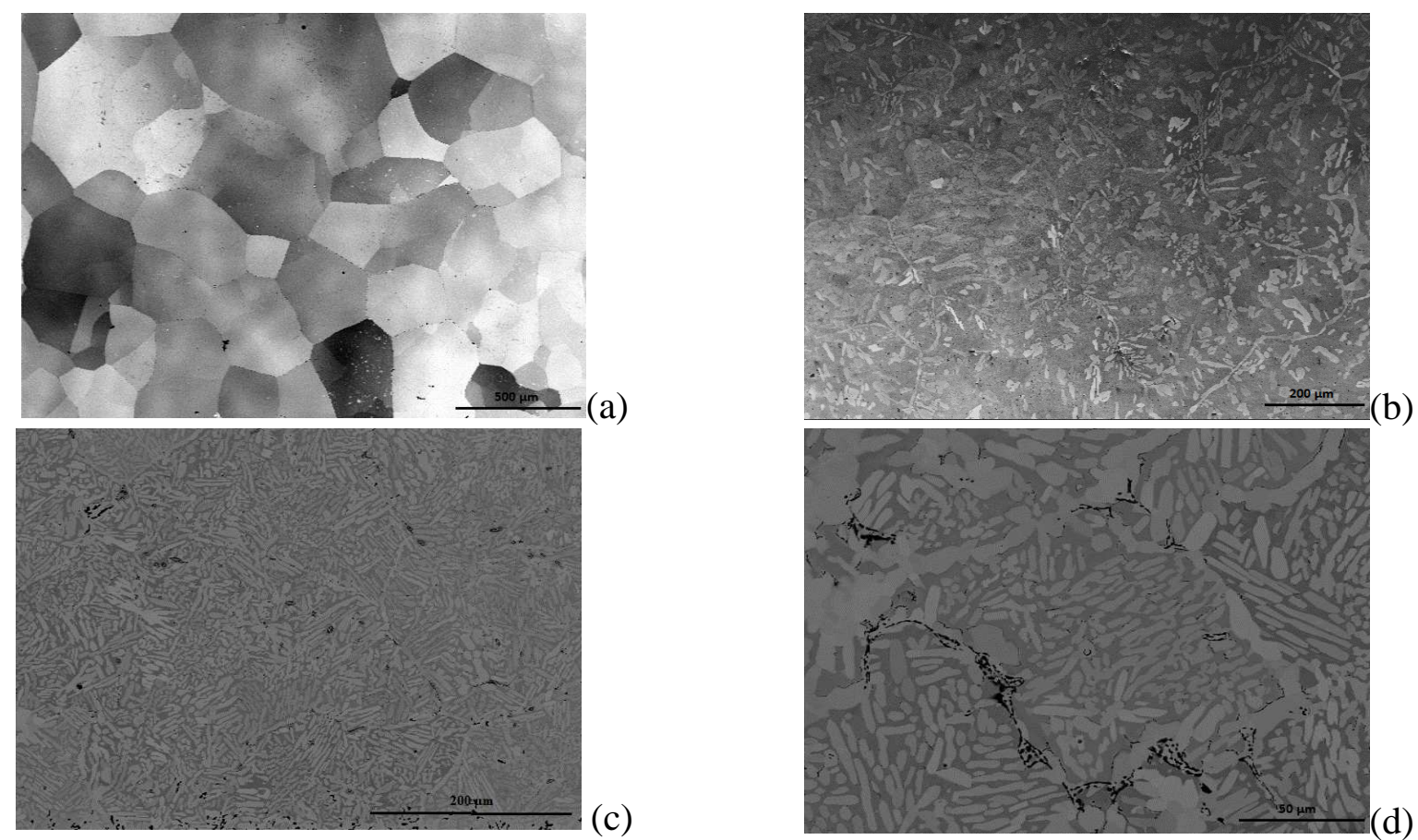

Fig. 3 (a) Backscattered SEM Micrograph of cast $+1200^{\circ} \mathrm{C} / 50 \mathrm{~h}$ heat-treated M1 (0at.\% Si) alloy showing equiaxed grains microstructure. (b) Backscattered SEM Micrograph of cast $+1200^{\circ} \mathrm{C} / 50 \mathrm{~h}$ heat-treated $\mathrm{M} 2(1$ at. $\% \mathrm{Si})$ alloy showing the presence of the $\delta$-phase. (c) \& (d) Backscattered SEM Micrographs of cast $+1200^{\circ} \mathrm{C} / 50 \mathrm{~h}$ heat-treated M3 ( 2 at. $\% \mathrm{Si}$ ) alloy showing an extensive precipitation of the $\delta$-phase and the presence of silicides at grains boundaries and in previous interdentritic regions. 


\section{$1400^{\circ} \mathrm{C} / 24 \mathrm{~h} /$ furnace cooling}

The heat treatment of $1400^{\circ} \mathrm{C} / 24 \mathrm{~h}$ leads to a significant growth of the grain size in M1 alloy (without silicon addition). As seen in Fig. 4a, the average grains size of the M1 alloy is higher than the millimetre. Whereas in M3 alloy heat-treated at the same temperature, it seems that the grain growth has been limited because of the $\delta$-phase and silicide precipitates at grains boundaries (Fig. $4 c)$. EDS analysis shows the presence of $(\mathrm{Nb}, \mathrm{Ti})_{3}(\mathrm{Al}, \mathrm{Si})$ at grain boundaries (Fig. $4 \mathrm{~d}$ and Table 2). Precipitation of silicide inside the grains is also observed (Fig. 4b). On the contrary to the treatment of $1200^{\circ} \mathrm{C} / 50 \mathrm{~h}$, the $\mathrm{M} 2$ alloy exhibits a precipitation of silicide at grain boundaries and none $\delta$ phase is observed after the treatment of $1400^{\circ} \mathrm{C} / 24 \mathrm{~h}$ (Fig. $4 \mathrm{c}$ ).
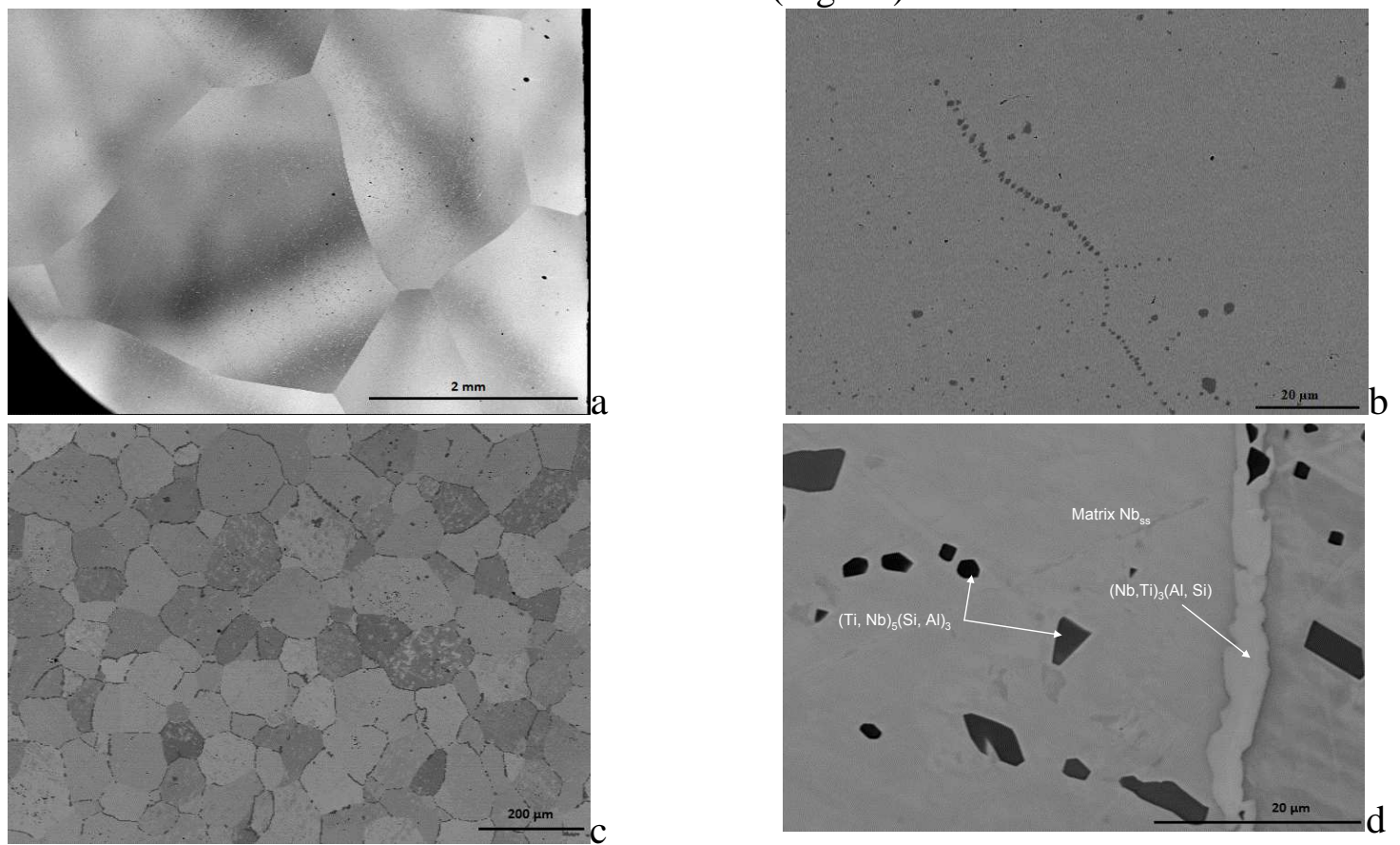

Fig. 4 (a) Backscattered SEM Micrograph of cast $+1400^{\circ} \mathrm{C} / 24 \mathrm{~h}$ heat-treated M1 (0at.\% Si) alloy showing equiaxed grains microstructure. (b) Backscattered SEM Micrographs of cast $+1400^{\circ} \mathrm{C} / 24 \mathrm{~h}$ heat-treated M2 alloy showing the presence of $\delta$-phase and silicide. (c) and (d) Backscattered SEM Micrographs cast $+1400^{\circ} \mathrm{C} / 24 \mathrm{~h}$ heat treated M3 alloy showing precipitation of silicide and $\delta$ - phase at grain boundaries.

\begin{tabular}{|c|c|c|c|c|c|c|}
\hline \multirow{2}{*}{ Alloy Composition (at.\%) } & \multirow{2}{*}{ Heat Treatment } & \multirow{2}{*}{ Phases } & \multicolumn{4}{|c|}{ Phases Composition (at.\%) } \\
\hline & & & $\mathrm{Nb}$ & $\mathrm{Ti}$ & $\mathrm{Al}$ & $\mathrm{Si}$ \\
\hline \multirow{2}{*}{$51 \mathrm{Nb}-34 \mathrm{Ti}-15 \mathrm{Al}$} & $1400^{\circ} \mathrm{C} / 24 \mathrm{~h}$ & $\mathrm{Nb}_{\mathrm{ss}}$ & 49 & 34.8 & 16.2 & - \\
\hline & $1200^{\circ} \mathrm{C} / 50 \mathrm{~h}$ & $\mathrm{Nb}_{\mathrm{ss}}$ & 48.8 & 33.5 & 17.7 & - \\
\hline \multirow{2}{*}{ 50.4Nb-33.6Ti-15Al-1Si } & $1400^{\circ} \mathrm{C} / 24 \mathrm{~h}$ & $\begin{array}{c}\mathrm{Nb}_{\mathrm{ss}} \\
\left.(\mathrm{Ti}, \mathrm{Nb})_{5} \mathrm{Si}, \mathrm{Al}\right)_{3}\end{array}$ & $\begin{array}{l}48.3 \\
32.6\end{array}$ & $\begin{array}{l}39.7 \\
34.4\end{array}$ & $\begin{array}{c}10.2 \\
6.6\end{array}$ & $\begin{array}{c}1.8 \\
26.4\end{array}$ \\
\hline & $1200^{\circ} \mathrm{C} / 50 \mathrm{~h}$ & $\begin{array}{c}\mathrm{Nb}_{\mathrm{ss}} \\
(\mathrm{Nb}, \mathrm{Ti})_{3}(\mathrm{Al}, \mathrm{Si})\end{array}$ & $\begin{array}{l}49.8 \\
54.2\end{array}$ & $\begin{array}{l}36.9 \\
26.4\end{array}$ & $\begin{array}{l}12.3 \\
16.4\end{array}$ & $\begin{array}{c}1.0 \\
3\end{array}$ \\
\hline \multirow{2}{*}{$49.8 \mathrm{Nb}-33.2 \mathrm{Ti}-15 \mathrm{Al}-2 \mathrm{Si}$} & $1400^{\circ} \mathrm{C} / 24 \mathrm{~h}$ & $\begin{array}{c}\mathrm{Nb}_{\mathrm{ss}}(\beta) \\
(\mathrm{Nb}, \mathrm{Ti})_{3}(\mathrm{Al}, \mathrm{Si}) \\
(\mathrm{Ti}, \mathrm{Nb})_{5}(\mathrm{Si}, \mathrm{Al})_{3}\end{array}$ & $\begin{array}{l}44.6 \\
47.7 \\
27.8 \\
\end{array}$ & $\begin{array}{l}37.9 \\
29.8 \\
33.5 \\
\end{array}$ & $\begin{array}{c}15.9 \\
19.2 \\
7.3 \\
\end{array}$ & $\begin{array}{r}1.6 \\
3.3 \\
31.4 \\
\end{array}$ \\
\hline & $1200^{\circ} \mathrm{C} / 50 \mathrm{~h}$ & $\begin{array}{c}\mathrm{Nb}_{\mathrm{ss}}(\beta) \\
(\mathrm{Nb}, \mathrm{Ti})_{3}(\mathrm{Al}, \mathrm{Si}) \\
(\mathrm{Ti}, \mathrm{Nb})_{5}(\mathrm{Si}, \mathrm{Al})_{3}\end{array}$ & $\begin{array}{l}41.7 \\
44.4 \\
26.3 \\
\end{array}$ & $\begin{array}{c}44.5 \\
32 \\
39.8 \\
\end{array}$ & $\begin{array}{c}12.3 \\
19.3 \\
9.2 \\
\end{array}$ & $\begin{array}{r}1.5 \\
4.3 \\
24.7 \\
\end{array}$ \\
\hline
\end{tabular}

Table 2 Alloy compositions and phase analysis (the accuracy of the EDX measurements is about $\pm 10 \%$ ).

For the Nb-34Ti-15Al alloy, the silicon solubility in the $\mathrm{Nb}$ solid solution, during the solidification seems to be between 1 at. $\%$ and 2 at. $\%$. Indeed, primary precipitates of silicide were observed at as-cast condition for the alloy with 2 at.\% of silicon, whereas in the case of M2 alloy (1 at.\% of Si), silicide precipitated only after the treatment of $1400^{\circ} \mathrm{C} / 24 \mathrm{~h}$.

Silicon addition seems to promote the precipitation of the $\delta$-phase instead of the precipitation of silicide in $\mathrm{Nb}-34 \mathrm{Ti}-15 \mathrm{Al}$ alloy, especially for the temperature of $1200^{\circ} \mathrm{C}$. Thus, one of the silicon 
addition effects is to increase the $\beta$ transus of the ternary system $\mathrm{NbTiAl}$, which was estimated by [6] at $1125^{\circ} \mathrm{C}$, and presently is to be higher than $1200^{\circ} \mathrm{C}$ with just 1 at. $\%$ of Si.

For higher heat treatment $\left(1400^{\circ} \mathrm{C} / 24 \mathrm{~h}\right)$, silicides were observed in both M2 and M3 alloys, whereas the $\delta$-phase was observed only in M3 alloy and in much lesser extent than at $1200^{\circ} \mathrm{C}$. According to previous observations, an addition of 2 at. $\%$ Si induces a $\beta$-transus higher than $1400^{\circ} \mathrm{C}$. The microstructure the alloy at this temperature consists in a mixture of $\beta\left(\mathrm{Nb}_{\mathrm{ss}}\right), \delta$-phase and silicide.

\subsection{Compression tests}

The compression stress-strain curves for the three alloys in as-cast condition are shown in Fig. 5. From theses $\sigma-\varepsilon$ curves, the $0.2 \%$ strain compressive yield strength has been determined. For both testing temperatures, room temperature and $800^{\circ} \mathrm{C}$, it was observed a significant increase of the yield strength with silicon content (Fig. 5). The yield strength was raised by $165 \mathrm{MPa}$ by increasing the silicon content to 1at.\%, and raised by $340 \mathrm{MPa}$ with 2 at.\% silicon addition. For the three tested alloys, the compression tests conducted at $800^{\circ} \mathrm{C}$ displayed a markedly decrease of yield strength compared to those carried out at room temperature (Fig. 5-6). However, the yield strength of the M1 alloy, without silicon addition, was mostly affected by the higher testing temperature than the M3 alloy containing 2 at.\% silicon, which exhibited a decrease of the yield strength to a lesser extend (Fig. 6). The compression stress-strain curve of the M2 alloy tested at $800^{\circ} \mathrm{C}$ shows a slight yield drop (Fig. 5).

Thus, the Fig. 6 clearly shows that, an addition of silicon, even in relatively low amounts, has a significant beneficial effect on the yield strength. Especially, its addition seems to improve the high temperature properties of the alloys.

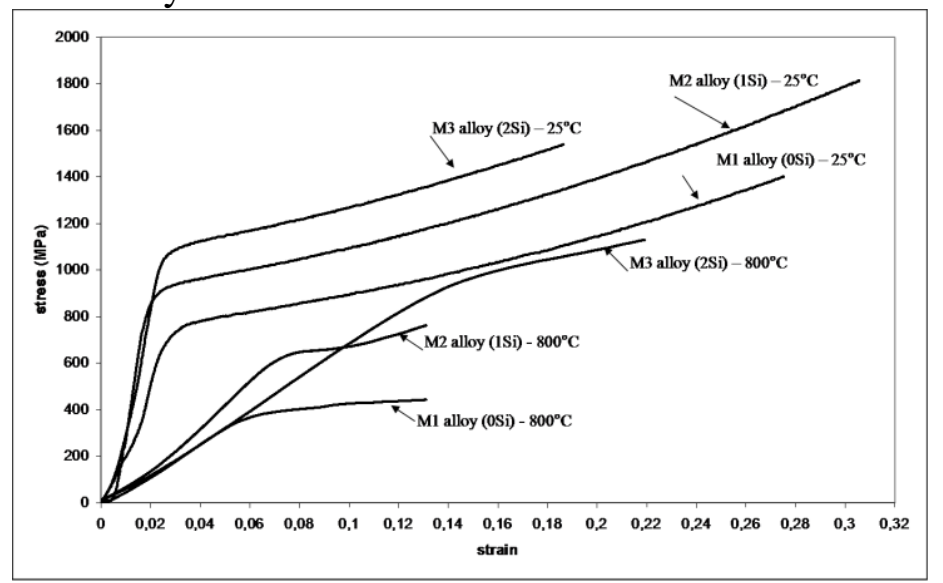

Fig. 5 Compression stress-strain curves for the three alloys at as-cast condition. The testing temperatures were roomtemperature and $800^{\circ} \mathrm{C}$ The strain rate was $10^{-4} \mathrm{~s}^{-1}$.

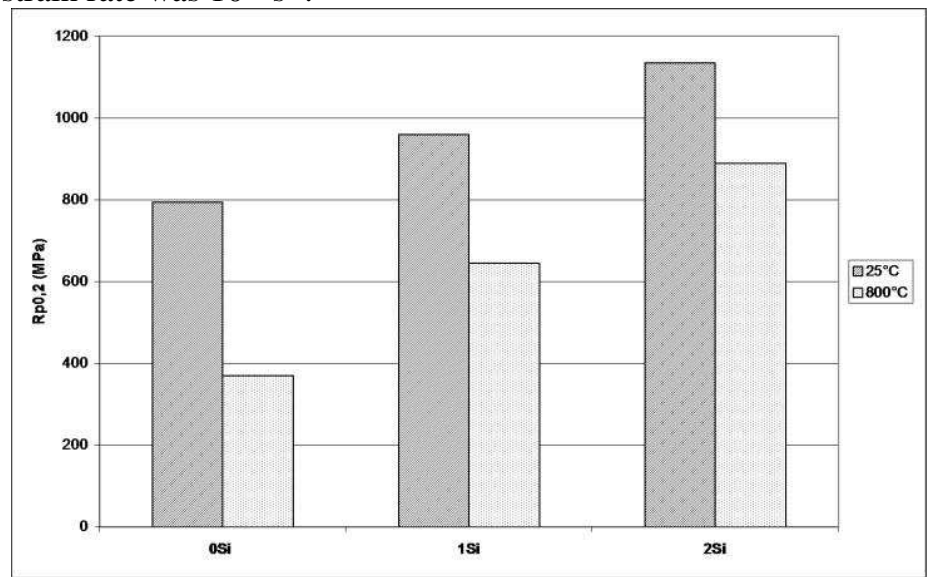

Fig. 6 Compression yield strength versus silicon content for the three alloys tested at room-temperature and at $800^{\circ} \mathrm{C}$. 


\section{Summary and conclusion}

In the present paper, $\mathrm{Nb}$-base refractory alloys based on $\mathrm{Nb}-35 \mathrm{Ti}-15 \mathrm{Al}$ (at.\%) and doped with small amount of $\mathrm{Si}$ ( 1 and 2 at\%) have been studied. The silicon addition effects on the microstructure features and mechanical properties (compression test) have been investigated.

$\mathrm{Si}$ addition promotes extensive precipitation of the $\delta-(\mathrm{Nb}, \mathrm{Ti}) 3(\mathrm{Al}, \mathrm{Si})$ phase instead of silicide formation, thereby increasing the $\beta / \delta$-transus temperature. Although a $\beta / \delta$-transus of $1125^{\circ} \mathrm{C}$ for the ternary composition is reported in the literature, the transus of the $\mathrm{NbTiAl}$-Si quaternary system is higher than $1200^{\circ} \mathrm{C}$ for 1 at. $\% \mathrm{Si}$ and higher than $1400^{\circ} \mathrm{C}$ for 2 at.\% Si.

Solubility of $\mathrm{Si}$ in Nbss appears to be low : although silicon content in Nbss after solidification is between 1 and 2 at $\%$, secondary silicide precipitation is observed at $1400^{\circ} \mathrm{C}$ even for 1 at $\%$ of silicon. The promotion of the $\delta$ phase by $\mathrm{Si}$ addition at $1200^{\circ} \mathrm{C}$ is also indicative of a low solubility in the $\mathrm{Nb}$ matrix, even at lower temperatures.

Compression tests were perfomed on as-cast condition, at both room temperature and $800^{\circ} \mathrm{C}$. For this condition, Nbss matrix seems to be sursaturated in Si. It should be noted that verification has been made that no modification of the microstructure took place during high temperature testing. According to the results, the silicon addition has a significant beneficial effect on the yield strength for both temperatures and this effect increases with silicon content. Mechanical characterization of other heat treatment conditions should give indication of the effect of $\delta$ phase and secondary silicides on mechanical behaviour and therefore ways to optimise this alloy system.

\section{References}

[1] E.S.K. Menon, P.R. Subramanian and D.M. Dimiduk, Scripta Met. et Mat., 27, p. 265 (1992)

[2] D.-H. Hou, S.S Yang, J. Sheyue and H.L. Fraser, Mat. Res. Soc. Symp. Proc., 322, MRS, Pittsburgh PA, p. 437 (1994)

[3] .S.K. Menon, P.R. Subramanian and D.M. Dimiduk, Met. And Mat. Trans. A, 27, p. 1647 (1996)

[4] K.J. Leonard and V.K. Vasudevan, Intermet., 8, p. 1257 (2000)

[5] K.J. Leonard, J.C. Mishurda and V.K. Vasudevan, Met. and Mat. Trans. B, 31, p. 1305 (2000)

[6] K.J. Leonard, J.C. Mishurda and V.K. Vasudevan, Mat. Sci. and Eng. A, 329, p. 282 (2002)

[7] S. Yang and V.K. Vasudevan, Scripta Met. Et Mat., 31, 7, p. 879 (1994)

[8] S. Dymek, M. Dollar and K.J. Leonard, Mat. Sci. and Eng. A, 239, p. 507 (1997)

[9] F. Ye, C. Mercer and W.O. Soboyejo, Met. Trans. A., 29, p. 2361 (1998)

[10] T.N. Marieb, A.D. Kaiser and S.R. Nutt, Mat. Res. Soc. Symp. Proc., 213, MRS, Pittburgh PA, p. 329 (1991)

[11] J. Shyue, D. Hou, M. Aindow and H. Fraser, Mater.Sci. Eng. A, 170, p. 1 (1993)

[12] S. Hanada, Y. Murayama and Y. Abe, Intermetallics, 2, p. 155 (1993)

[13]U.R. Kattner and W.J. Boettinger, Mat. Sci. and Eng. A, 152, p. 9 (1992)

[14] V.T. Witusiewicz, A.A Bondar, U. hecht, T. Ya. Velikanova, J.of All. and Comp., 472, p. 133 (2009)

[15] J. Shyue, D.H Hou, S.C. Johnson, and H.L. Fraser, Mat. Res. Soc.Symp. Proc., 288, p. 573 (1992) 